supreme leader) did not hide their displeasure and mistrust after it became known that Russia was using the Iranian military air base.

The researcher concludes that relations between Iran and Russia went up and down during the 19th and 20th centuries. Political relations between states did not affect the socio-cultural sphere. Having considered the dynamics of development of relations at the state and socio-cultural levels over the past two centuries, Abolfazl Delavari considers it necessary to make some suggestions:

1) Russian politicians need to rethink the structure of relations with Iran and make efforts to eliminate the negative consequences;

2) The development of the socio-cultural sphere should take place not only through governments, but also through intellectual and cultural elites, economic leaders, civil society organizations and the development of bilateral tourism;

3) The development of academic and scientific contacts can contribute to the strengthening of comprehensive relations and strategic balance between the state and the society of both countries.

Author of the abstract - Elena Dmitrieva

AZIZ NIYAZI. SYRIA: HUMANITARIAN LOSSES OF THE WAR // The article was written for the bulletin "Russia and the Moslem World".

DOI: $10.31249 / \mathrm{rmw} / 2019.02 .02$

Keywords: Human Development Index; quality of life in Syria, violent conflicts, refugees, humanitarian losses, poverty rate, food security.

\title{
Aziz Niyazi,
}

$\mathrm{PhD}$ (History), Senior Research Associate,

Center for Central Asian, Caucasian and Volga-Urals Studies, Institute of Oriental Studies, RAS

Abstract. In the article there are provisional results of humanitarian losses in Syria, since 2011 on the basis of the UN 
reports and data of some authoritative international organizations. It is considered a problem of decline in quality of life upon indicators of human development, destruction of social institutes, mass displacement of refugees.

It is not possible to measure destructive results of war in Syria conclusively. Though large-scale military operations are completed, coals of the violent conflict still smolder in certain regions of the country and continue to bring Syrians travails. Nevertheless, provisional results of this humanitarian disaster of the 21st century look appallingly. In pre-war days Syria was rather safe middle-income country in economic terms, but at the end of 2014 four of five Syrians lived in poverty, 64.7 percent of them in the conditions of desperate poverty. These people were not able to provide the main needs necessary for survival of households and had no opportunity to satisfy own basic needs, including for food. 30 percent of the population appeared to be in extreme poverty, many of whom experienced chronic hunger in severe forms.

According to the last report of United Nations Development Programme on human development published in 2018, the level of quality of life of SAR citizens during 2012-2017 in the world ranking by Human Development Index (HDI) fell by 27 positions. Thereby Syria showed the highest rate in the world in terms of abrupt public regression. Conflict-ridden Libya and Yemen follow up. The quality of life in them for the same period in the world ranking by HDI decreased by 26 and 20 points respectively. It's worth reminding that HDI is counted by such basic measurements of people's wellbeing as: long and healthy life, duration and education level, gross national income per capita, level of poverty, safety and inequality, including gender, ecological situation, condition of the rights and opportunities of citizens, social and economic stability.

According to the specialists' research of the World Bank in the beginning of 2017 from 400 to 470 thousand people died in Syria in war-time, $7 \%$ of housing space was destroyed and $20 \%-$ 
partially damaged, about a half of medical and educational institutions were damaged or completely destroyed. Since 2011 until the end of 2016 cumulative losses in GDP were 226 billion dollars that exceeded GDP of Syria approximately four times in 2010. More than a half of the population of the country had to leave their houses that became the largest crisis related to refugees since World War II. According to the report of the World Bank in the first five years of the conflict 538 thousand workplaces on the average were annually destroyed. In 2015 unemployment rate among youth reached 78 percent, 6.1 million of young Syrians did not work and did not study in any form about 6 of every 10 citizens of SAR lived in desperate poverty. Damage caused to infrastructure led to the general health deterioration of the population throughout the country and to renewal of spread of such infectious diseases as poliomyelitis. Data for the beginning of 2017 show that more Syrians died because of inaccessibility to medical care rather than owing to warfare. Cumulative losses of GDP as a result of failure in social and economic system by 20 times exceeded the losses caused by physical destruction within first six years of the conflict. These failures reduced impetus to participation in production activity, interrupted economic ties and supply chains. Destruction of social and economic structures and relationship, credibility gap uniting people are more considerable factors impeding rebuilding of the country than physical injuries. Their recovery will become more difficult task, than restoration of physical infrastructure - analysts of the World Bank come to conclusion.

In fact collective losses of the human capital can be restored quite long time - throughout life of several generations. There is reason to hope that this process will not drag on for so long period in Syria. Nevertheless, in development planning of the country it is necessary to consider inevitable shortage of proficiency of the Syrian citizens due to outflow of highly qualified specialists, high unemployment rate (57\% of able-bodied citizens in 2017), permanent disappearance of proper school and other education, 
malnutrition causing retardation of growth among children, outflow of more than 5 million refugees abroad. In Syria there are about 6 million people - the internally displaced people who left their houses during war. Mass displacing population (in total more than $60 \%$ of citizens of SAR) leaned hard on the resources of accepting communities and countries.

Miseries of war in Syria caused negative humanitarian shifts in the nearby states. Migration of Syrians mainly to neighboring states brought to notable tension on housing and labour markets, loss of quality and availability of public services, lack of food security. As estimated by United Nations High Commissioner for Refugees (UNHCR) in the middle of 2017 in the territory of the countries of the Middle East and North Africa, bordering on Syria, and also in Turkey there were 5.05 million registered Syrian refugees. For comparison in disproportion in comparison with the European region specialists of the UNHCR note that from April, 2011 till May, 2017 there were given 884,461 requests for asylum in Europe by citizens of Syria. The most difficult situation in connection with acceptance of refugees developed in Lebanon. Though the country was not directly involved in the Syrian conflict, it sharply felt its destructive side issues. For June 30, 2017 in Lebanon there were registered 1,011,366 Syrian refugees (99\% of the number of all refugees). They made $23 \%$ of local population of pre-war time.

Crisis in SAR made exclusively notable impact on Lebanon. As the Lebanese economy was closely connected with Syrian, with the beginning of the conflict a sharp slowdown of growth rates followed. If in pre-crisis years this indicator was at the level of $10 \%$, then in 2011-2014 it was hovering around 1-2\%. Traditional trade routes were interrupted, credit of investors and consumers was undermined, safety level decreased. From 2013 to 2014 export volumes and direct foreign investments decreased by $25 \%$, and tourism, since the beginning of crisis, by $60 \%$. The public debt to the middle of 2014 reached 141\% of GDP. With inflow of Syrian refugees the labour supply increased by $50 \%$, the number of pupils in public schools grew by $30-35 \%$. There was peak demand for 
services of state health care. Crisis made disproportionately strong impact on already vulnerable households. It was promoted not only by increased competition at the market of unskilled labour also by unreasonable demand for public services, but also that fact that a half of refugees lived in a third of the poorest regions of the country. According to calculations of the World Bank, owing to the Syrian conflict the share of the population living in poverty by the end of 2014 made 3.9\%. Poor people in Lebanon became even poorer. Thus the war in Syria aggravated already intense internal situation in intercommunal relations in Lebanon.

The Syrian conflict first being of internal orientation very quickly gained cross-border, regional character and moved to the international level. Parallel to this trend it became more complicated and got more and more long form. Its destructive cumulative impact on economy, infrastructure, food systems, agricultural industry, social institutes and in general on ability of people to overcome shocks increased. Huge humanitarian losses of war in Syria is a misfortune not only of its citizens, it is spread over the borders and continents as echo.

2019.02.014. Naima Nefliasheva. HOW "NEW MUHAJIRS" FROM RUSSIA LIVE IN TURKEY. MIGRATION OF RUSSIAN MUSLIMS IN THE 2000s // "Azia i Afrika segodnya," Moscow, 2018, № 8, P. 27-34.

Keywords: Turkey, Russia, North Caucasus, temporary migration of Russian Muslims, "new muhajirs" Islam.

\section{Naima Nefliasheva,}

$\mathrm{PhD}$ (History), Associate Professor, Institute of African Studies RAS

The article analyzes the reasons for the migration of Russian Muslims to Turkey, and singles out groups of so-called "new muhajirs." 